\title{
Intrahypothalamic Implantation of Progesterone in Castrated Male Whiptail Lizards (Cnemidophorus inornatus) Elicits Courtship and Copulatory Behavior and Affects Androgen Receptor- and Progesterone Receptor-mRNA Expression in the Brain
}

\author{
David Crews, John Godwin, Vesta Hartman, Michael Grammer, Ellen A. Prediger, and Rebecca Sheppherd \\ Department of Zoology and Institute for Reproductive Biology, University of Texas, Austin, Texas 78712
}

\begin{abstract}
A primary tenet of behavioral neuroendocrinology is that gonadal steroid hormones act on limbic nuclei to activate mating behavior in vertebrates. Traditionally, research has focused on the regulation of male-typical sexual behavior by testicular androgens and female-typical sexual behavior by ovarian estrogen and progesterone. Indeed, progesterone generally is regarded as an antiandrogen, acting centrally to inhibit sexual behavior in males. However, experiments with lizards, and more recently with rats, have challenged this paradigm. For example, exogenous progesterone induces mating behavior in some, but not all, castrated male whiptail lizards. The present study determined that implantation of progesterone into the anterior hypothalamus preoptic area of castrated, progesterone-sensitive males completely restored sexual behavior but failed to elicit sexual activity in castrated, progesterone-insensitive males. Further, androgen receptor- and progesterone receptor-mRNA expression in specific brain regions was significantly different in progesteronesensitive versus progesterone-insensitive animals. Progesterone-
\end{abstract}

sensitive males showed significantly higher relative abundance of androgen receptor-mRNA in the preoptic area, amygdala, and lateral septum, as compared with progesterone-insensitive animals receiving the same treatment. In contrast, progesterone receptor-mRNA abundance was lower in preoptic area of progesterone-sensitive males than in progesterone-insensitive males. No differences were found in the baseline abundance of androgen receptor- or progesterone receptor-mRNA in these nuclei between control groups of progesterone-sensitive and progesterone-insensitive males who were castrated but not implanted. This suggests that progesterone differentially regulates its own receptor as well as androgen receptor in areas of the brain involved in the control of sexual behavior of males and that the nature of this regulation shows individual variability.

Key words: steroid hormone receptor; gene expression; intrahypothalamic implantation; septum; amygdala; preoptic area; sexual behavior; autoregulation; androgen; progesterone; reptile; lizard; male
In the little striped whiptail lizard (Cnemidophorus inornatus), as in many other vertebrates, males rely on elevated circulating levels of androgens for the seasonal activation of sexual behaviors (Lindzey and Crews, 1986). However, in a subset of these lizards, exogenous progesterone can also reinstate sexual behavior in castrated males (equals progesterone-sensitive or P-sensitive males) (Lindzey and Crews, 1986, 1988a,b). Restoration of sexual behavior in $\mathrm{P}$-sensitive males by synthetic progestin agonists indicates that it is progesterone, and not a metabolite of progesterone, that produces this behavioral effect (Lindzey, 1988a); binding studies suggest that progesterone receptor (PR) mediates this response (Lindzey and Crews, 1993). Initially, this progesterone activation of sexual behavior

Received July 9, 1996; revised Aug. 29, 1996; accepted Aug. 30, 1996.

This research was supported by National Institute of Mental Health MERIT Award 41770, Research Scientist Award 00135, and Training Grant 18837 (all to D.C.), National Institutes of Health National Research Service Award NS09219 (to J.G.), University of Texas Undergraduate Biomedical Training Program (to V.H. and M.G.), and National Institutes of Health National Research Service Award MH10372 (to E.A.P.). We thank Ron and Sherry Hall and Ross and Frank Stavely for their hospitality and assistance with lizard collections in Sanderson, Texas, and the Southwestern Research Station of the American Museum of Natural History for the use of its facilities. We also thank Donald K. Clifton for providing the Grains image analysis program.

Correspondence should be addressed to Dr. David Crews, Institute of Reproductive Biology and the Department of Zoology, University of Texas at Austin, Austin, TX 78712.

Dr. Prediger's present address: Ambion Incorporated, Austin, TX 78744.

Copyright (C) 1996 Society for Neuroscience $0270-6474 / 96 / 167347-06 \$ 05.00 / 0$ in castrated male whiptail lizards was puzzling, given the well known observation that androgen-dependent sexual behaviors in male mammals and birds are inhibited by progestins (Diamond, 1963; Ericksson et al., 1967; Erpino, 1973; Griffo and Lee, 1973; Bardin et al., 1984; Bottoni et al., 1985). However, inspection of the original reports will show that the milligram amounts administered were likely to result in circulating concentrations of hormone in excess of the normal physiological range and, hence, were pharmacological. Further, physiological studies indicate that male rats have a pronounced circadian rhythm in progesterone secretion, with fivefold higher peak levels occurring at the onset of dark phase of the photoperiod when most sexual activity occurs (Kalra and Kalra, 1977).

Experiments with another lizard (Young et al., 1991) and, more recently, rats (Witt et al., 1994, 1995) indicate that, whereas pharmacological dosages of progesterone inhibit sexual behavior in intact and in castrated, androgen-treated males, lower dosages that result in circulating levels within the physiological range stimulate sexual behavior in castrated males. Such progesteronetreated castrates court and copulate with females with an intensity equal to that shown by castrates receiving androgen replacement therapy. Further, subthreshold dosages of progesterone and androgen synergize to elicit mounting behavior in castrated males, much as estrogen and progesterone do in eliciting sexual receptivity in female lizards and mammals (Lindzey and Crews, 1988a; Young et al., 1991; Witt et al., 1995). It seems, therefore, that 
progesterone and androgen both are necessary for the display of sexual behavior in intact males, but neither is sufficient for complete restoration of sexual behavior after castration. Thus, in terms of its role in the neuroendocrine control of sexual behavior, progesterone may be as much a hormone that affects mounting and copulatory behavior in males as it affects receptive behavior in females.

Exploring the neuroendocrine mechanism underlying progesterone-activated courtship and copulatory behavior in male whiptail lizards may provide insights into the regulation of sexual behavior in male vertebrates generally. We find that males who are behaviorally sensitive to systemic progesterone are also responsive to intrahypothalamic implants of progesterone, whereas P-insensitive males do not respond to such implants. Further, P-sensitive males exhibit significantly higher AR-mRNA expression than P-insensitive males in the medial preoptic area (POA), lateral septum, and amygdala, brain regions known to be involved in the regulation of sexual behavior in males. These same P-sensitive males had significantly lower expression of PR-mRNA in the medial and periventricular POA. P-sensitive and P-insensitive males that did not receive an intrahypothalamic implant did not have differential baseline abundance of AR- or PR-mRNA in these nuclei.

\section{MATERIALS AND METHODS}

Animals. Cnemidophorus inornatus were captured near Sanderson, Texas, and in and around Portal, Arizona. The lizards were transported to the University of Texas at Austin, where they were maintained as described in Lindzey and Crews (1986). Male study animals were housed individually, and females were housed in groups of four with one male.

Surgical procedures. All surgery was performed by using hypothermia as anesthetic. Castrations were performed by the technique described in Crews et al. (1978). Briefly, an incision was made on each side of the animal lateral to the abdominal midline. Silk ligatures were used to cut off blood flow to the testes, which subsequently were removed. Gonadal arteries and veins were cauterized to prevent further bleeding, and the incision was closed with silk sutures passing through both the skin and peritoneum. All of the animals included in the study displayed male typical courtship and copulatory behaviors in the laboratory before castration. Males were castrated at least 2 weeks before receiving intraperitoneal implants and were behavior-tested to insure that the castration was effective.

Intraperitoneal implants of progesterone were made with similar surgical technique. Intraperitoneal hormone implants were made of $10 \mathrm{~mm}$ of SILASTIC surgical tubing (inner diameter, $1.47 \mathrm{~mm}$; outer diameter, $1.96 \mathrm{~mm}$; Dow Corning, Midland, MI) filled with progesterone (Sigma, St. Louis, MO), as described previously in Lindzey and Crews (1986). The ends of the tubing were sealed with SILASTIC adhesive, and a $1 \mathrm{~cm}$ piece of silk surgical thread was embedded in one of the ends to serve as an anchor after surgical implantation.

With the use of a Kopf stereotaxis modified for small reptiles, each experimental animal received an intrahypothalamic progesterone implant using methods detailed in Rozendaal and Crews (1989). The point of intersection of the two frontal parietal scales and the interparietal scale was used as a reference point to determine stereotaxic coordinates. A 1-mmround dental burr was used to drill a hole in the skull overlying the target area. A cannula of 30 gauge hypodermic tubing (Hamilton, Reno, NV) containing progesterone was lowered to the desired site, and the hormone pellet was ejected by pushing a cleaning wire through the cannula. The cannula was withdrawn, and the hole in the skull was filled with Gelfoam. Animals were allowed $24 \mathrm{hr}$ to recover in their home cages before behavioral testing began.

Intrahypothalamic hormone implants consisted of progesterone, red Crayola wax, and bone wax in a 3:1:9 ratio by weight. Implant pellets were formed by tapping the end of the cannula into the mixture. The cylindrical implants averaged a $140 \mu \mathrm{m}$ inner diameter $\times 0.5 \mathrm{~mm}$ in length, indicating an implant volume of $0.008 \mathrm{~mm}^{3}$. This represents $<10 \%$ of the volume of the anterior hypothalamus (AH)-POA of a male C. inornatus, which averages $0.096 \mathrm{~mm}^{3}$ (Crews et al., 1990; Wade et al., 1993). Pellets were found to have an average mass of $22.4 \mu \mathrm{g}$ (mean of five pellets weighed on a Cahn microbalance) and, thus, to contain an average dosage

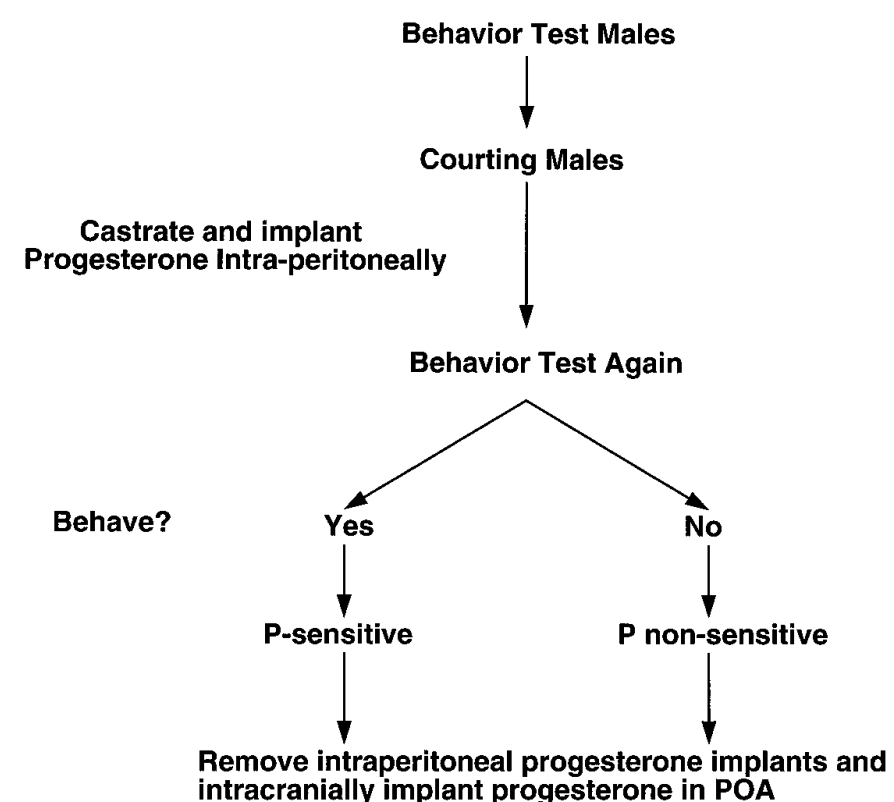

intracranially implant progesterone in POA
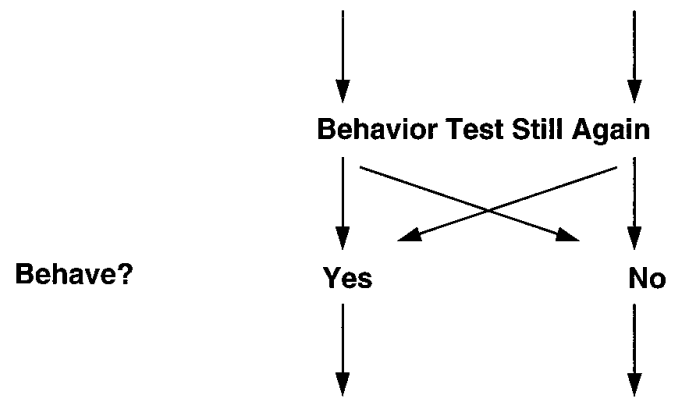

Take Brains and compare AR- and PR-mRNA expression by in situ hybridization

Figure 1. Schematic illustrating steps in experiment. Control males experienced the same procedures, with the exception of intrahypothalamic implantation. For details, see Experimental Design.

of $\sim 5.20 \mu \mathrm{g}$ of progesterone per implant. Each experimental animal received one intrahypothalamic implant targeted for the AH-POA (coordinates $+1.85 \mathrm{~mm}$ ventral and $-0.35 \mathrm{~mm}$ posterior to the reference point). Control animals did not receive an intrahypothalamic implant.

Behavioral testing procedure. All behavioral tests were conducted by introducing a stimulus-receptive female into the home cage of the experimental male. Tests were conducted during the high activity period between 10:00 A.M. and 2:00 P.M. A 3 min test was administered daily to all subjects during periods of behavior testing, and tests were scored in accordance with the hierarchy of sexual behavior described by Lindzey and Crews (1986). Animals showing no interest at all in the stimulus female were scored 0 , those that approached and made contact scored 1 , swiggle walking received a 2 , mounting a 3 , riding a 4 , assuming a copulatory posture a 5 , and copulating a 6. Increasing scores represent increasing intensity of male sexual behavior. All but the last behavior testing period consisted of five sequential days of testing. An animal scoring a 3 or greater in three of the five tests was considered as giving a positive response and classified as a "courter." For the tests conducted after intrahypothalamic implantation, animals were tested for seven consecutive days.

Experimental design. The present report combines traditional behavioral endocrine methods, including castration, hormone replacement therapy, and intrahypothalamic hormone implantation, with a modern molecular method, quantitative in situ hybridization to identify AR- and PR-mRNAs in brain nuclei. The experimental design is summarized in Figure 1. Intact males were tested for courtship and copulatory behavior. Those displaying sexual responses as described above ("courters") were used for the study. After behavior testing in the intact condition, males were castrated, allowed $10 \mathrm{~d}$ to recover, and then tested to insure the extinction of sexual behavior. Then animals were given intraperitoneal pellets of progesterone, allowed a $10 \mathrm{~d}$ 
Table 1. Comparison of relative PR- and AR-mRNA abundance in hypothalamic nuclei of strong-courting and weak-courting males in intrahypothalamic P-implanted and castrated nonimplanted control conditions

\begin{tabular}{|c|c|c|c|c|c|c|}
\hline \multirow[b]{2}{*}{ Nucleus } & \multicolumn{2}{|c|}{ Intrahypothalamic P-implanted } & \multirow[b]{2}{*}{$t$ test } & \multicolumn{2}{|c|}{ Nonimplanted control } & \\
\hline & P-sensitive & P-insensitive & & P-sensitive & $\mathrm{P}$-insensitive & \\
\hline \multicolumn{7}{|l|}{ PR-mRNA } \\
\hline MPOA & $12.63 \pm 0.70(11)$ & $15.90 \pm 1.40(5)$ & $p<0.05$ & $8.43 \pm 1.64(6)$ & $9.10 \pm 0.54(6)$ & N.S. \\
\hline PvPOA & $25.19 \pm 3.30(11)$ & $32.38 \pm 2.20(5)$ & $p<0.05$ & $22.35 \pm 1.63(6)$ & $20.67 \pm 1.56(6)$ & N.S. \\
\hline \multicolumn{7}{|l|}{ AR-mRNA } \\
\hline MPOA & $11.11 \pm 1.00(11)$ & $8.21 \pm 0.58(5)$ & $p<0.01$ & $23.79 \pm 3.04(6)$ & $23.47 \pm 4.04(6)$ & N.S. \\
\hline PvPOA & $4.49 \pm 0.42(11)$ & $4.12 \pm 0.94(5)$ & N.S. & $8.92 \pm 0.67(6)$ & $11.62 \pm 3.26(6)$ & N.S. \\
\hline Amygdala & $21.24 \pm 1.63(11)$ & $16.23 \pm 1.89(5)$ & $p<0.05$ & $41.66 \pm 3.70(6)$ & $42.92 \pm 7.48(6)$ & N.S. \\
\hline Lateral septum & $18.43 \pm 1.45(11)$ & $13.52 \pm 0.55(5)$ & $p<0.01$ & $27.24 \pm 2.73(6)$ & $28.74 \pm 3.37(6)$ & N.S. \\
\hline
\end{tabular}

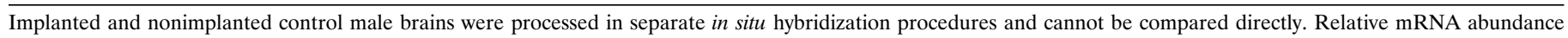
is assessed by silver grain density over labeled cells (mean \pm 1 SEM). Numbers in parentheses equal $n$ values.

N.S., Not significant.

recovery, and behavior-tested again to determine whether sexual behavior was reinstated by systemic progesterone treatment. Males for whom the sexual behavior was reinstated with systemic progesterone were classified as P-sensitive; those in which sexual behavior was not reinstated were classified as P-insensitive. The intraperitoneal progesterone pellets were then removed, and the animals again were tested for extinction of behavior. Finally, each experimental animal was implanted (or not) with an intrahypothalamic progesterone pellet targeted to the AH-POA and tested double blindly for stimulation of sexual behavior (experimental: $11 \mathrm{P}$-sensitive, $7 \mathrm{P}$-insensitive).

A single score of 3 or greater was designated a positive response, and these animals were killed immediately. If an animal had not given a positive response by the seventh day of testing, the animal was considered to have shown no response and was killed at that time. A second group of males was given five behavior tests and designated as courters or noncourters on the basis of behavioral scores as described above. After castration and extinction of sexual behavior, these males were tested for $P$ sensitivity in the reinstatement of courtship behavior by intraperitoneal implants of progesterone as described above. After their classification as either P-sensitive $(n=6)$ or P-insensitive $(n=6)$, the implants were removed, and the males were allowed 1 week to clear the exogenous progesterone before they were killed for brain removal. This second group of males was intended as a control group comparing P-sensitive and P-insensitive males in the unimplanted condition and under similar baseline hormonal conditions.

Tissue samples. Animals were killed by rapid decapitation and the intact brains immediately removed, frozen on dry ice, and stored at $-80^{\circ} \mathrm{C}$ until sectioning. Coronal cryosections $(20 \mu$ thick $)$ were melted onto RNase-free poly-L-lysine-coated microscope slides, dried at room temperature, and stored in slide boxes with desiccant at $-80^{\circ} \mathrm{C}$. Sections were collected across a series of seven slides so that adjacent sections could be hybridized to different probes.

In situ hybridization and silver grain quantification. The protocols and validation of the in situ hybridization, autoradiography, and grain quantification procedures used in this study have been described (Young et al., 1994, 1995; Godwin and Crews, 1995). Briefly, all slides in all treatment groups were processed in the in situ hybridization procedure at the same time. After hybridization, slides were dipped in Kodak NTB-2 emulsion and allowed to expose at $4^{\circ} \mathrm{C}$ for $11 \mathrm{~d}$ for quantification of PR-mRNA and 3 weeks for AR-mRNA, developed in Kodak D-19 developer, and fixed. Silver grain density was defined as number of grains per cluster, in which clusters were groups of silver grains lying over cell somata in discrete, cresyl violet-defined brain nuclei on sections that were matched anatomically between individual lizards [Young et al. (1994), their Figs. 2-4] (see Fig. 2 for anatomical maps of the whiptail brain). Silver grain density was quantified in the medial and periventricular POA for PR-mRNA and in the medial and periventricular POA, amygdala, and lateral septum for AR-mRNA with the "Grains" program (Donald K. Clifton, University of Washington, personal communication) on a Macintosh IIci computer equipped with an image capture system exactly as described previously (Young et al., 1995). Because of the small size of whiptail lizard brains, well-labeled cells are clustered typically on only one section of experimental slides. For both mRNA species, we counted the 10 most densely labeled cells in the medial POA, periventricular POA, and lateral septum and the 20 most densely labeled cells in the amygdala, as in previous work
(Young et al., 1995). The control slides hybridized to sense strand control probes exhibited uniform background densities of silver grains and no specific labeling of cells. Sample sizes differed for different nuclei because sections were sometimes lost in cryosectioning.

Statistical analysis. The proportions of males in the P-sensitive and P-insensitive groups in which behavior was reinstated by intrahypothalamic progesterone implants were compared with Fisher's Exact test (Zar, 1984). Mean silver grain densities (grains/cluster) measured in given nuclei were compared between P-sensitive and P-insensitive males with two-sample $t$ tests. Data were $\log _{10}$-transformed to reduce heterogeneity of variance between comparison groups, as necessary (Zar, 1984). All analyses were performed by Systat 5.1.2 on an Apple Macintosh computer.

\section{RESULTS}

\section{Intrahypothalamic progesterone implantation and behavior reinstatement}

Intrahypothalamic progesterone implants reinstated sexual behavior in a significantly higher proportion of males identified as $\mathrm{P}$-sensitive on the basis of systemic progesterone administration (8/11) than in males identified as P-insensitive (1/7; Fisher Exact test, $p<0.05)$.

\section{PR- and AR-mRNA expression in P-sensitive and $P$-insensitive males}

P-sensitive implanted males showed significantly lower abundance of PR-mRNA than P-insensitive implanted males in both the medial and periventricular POA ( $p<0.05$ in each case) (Table 1, Fig. 2). The pattern was opposite for AR-mRNA in the medial POA, in which P-sensitive implanted males had significantly higher ARmRNA abundance $(p<0.01)$. AR-mRNA abundance did not differ between the groups for the periventricular POA $(p>0.5)$. $\mathrm{P}$-sensitive implanted males also showed significantly higher ARmRNA abundance than P-insensitive implanted males in the amygdala externae $(p<0.05)$ and lateral septum $(p<0.01)$ (Table 1, Fig. $2)$. There were no statistical differences in PR- or AR-mRNA abundance in these nuclei among nonimplanted P-sensitive and P-insensitive control males (Table 1). Because the individuals receiving intrahypothalamic implants were processed in separate in situ hybridization procedures from the nonimplanted control males, these groups cannot be compared directly.

The cryosectioning and preparation for in situ hybridization interfered with locating the implant in some of the individuals, but implant position was identified in over one-half of the brains and did not differ between P-sensitive and P-insensitive animals. There were also no significant differences found in steroid receptor expression patterns in the medial or periventricular POA between the side of 

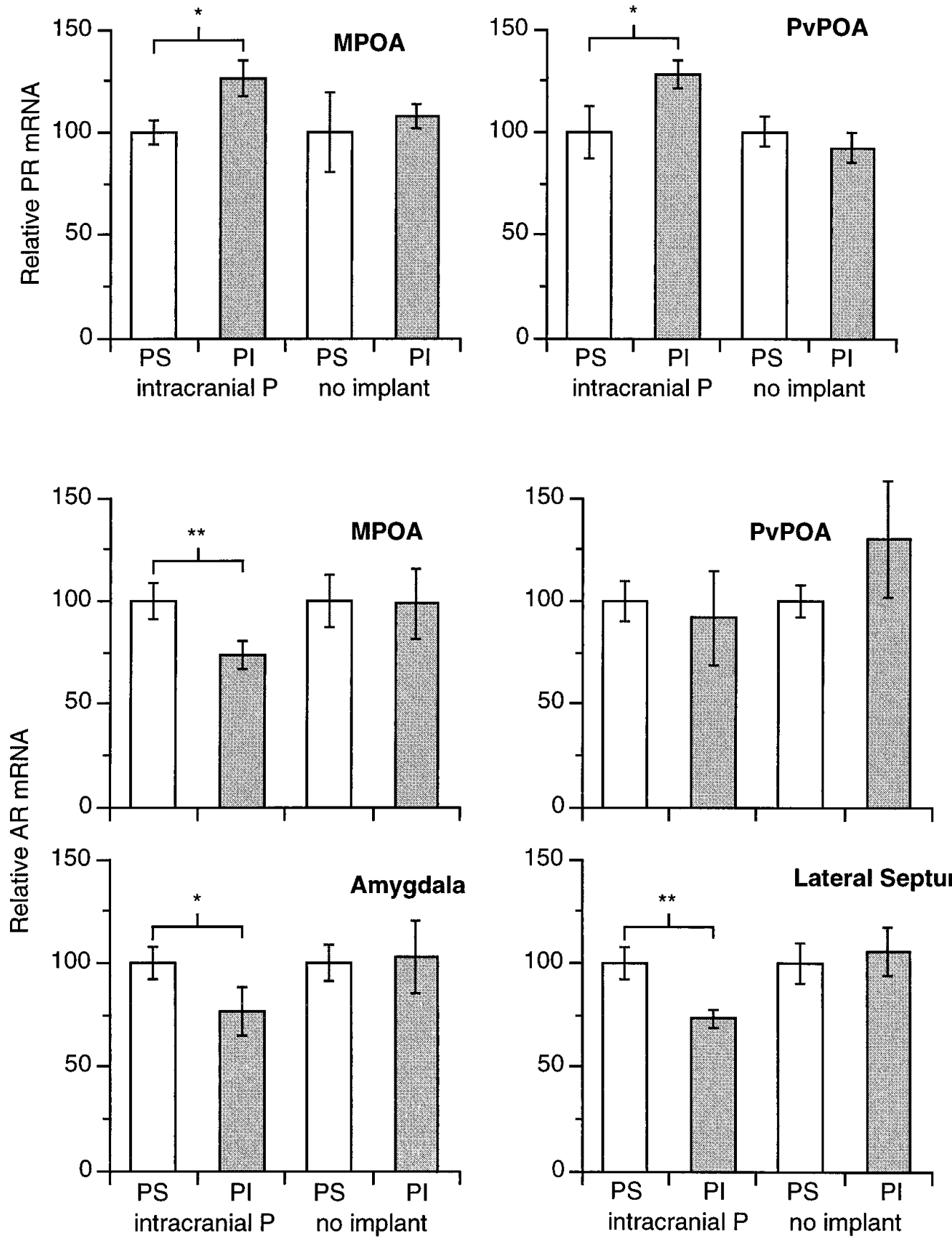

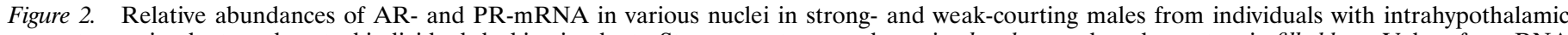

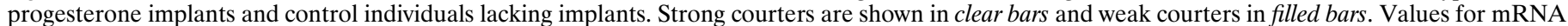
relative abundances in weak courters are expressed relative to those in strong courters (defined as $100 \%$ ) for each treatment group.

the brain receiving the implant and the side left intact (either with the $\mathrm{P}$-sensitive and P-insensitive groups considered separately or when lumped together) ( $p>0.5$ paired-sample $t$ tests).

\section{DISCUSSION}

Intrahypothalamic progesterone administration was effective in reinstating sexual behavior in castrated males determined previously to be P-sensitive by systemic administration of progesterone, indicating that the behavioral effects of exogenous progesterone are mediated centrally, rather than peripherally. The site of action is likely one or more nuclei of the anterior hypothalamus and preoptic area (AH-
POA), such as the medial and periventricular POA. In vertebrates, the neural circuit mediating mounting and intromission behavior involves the AH-POA as the final common pathway. Not only is it a target area of sex steroid hormones, but administration of androgen directly into this area of castrated, sexually inactive males stimulates mounting and intromission behavior, whereas bilateral lesions of this area in sexually active males abolish such behavior (Crews and Silver, 1985; Sachs and Meisel, 1994).

P-sensitive males with intrahypothalamic implants had significantly higher AR-mRNA abundance, as compared with P-insensitive males in the medial POA, amygdala externae, and lateral septum, areas 
that exhibit the strongest labeling for AR-mRNA in the whiptail lizard brain (Young et al., 1994). The medial POA is critical to the control of male-typical sexual behavior in whiptail lizards (Kingston and Crews, 1994), and the amygdala has been implicated in the mediation of sexual behavior in various species (Kling and Brothers, 1992; Sachs and Meisel, 1994). In the green anole lizard (Anolis carolinensis), bilateral lesions of the amygdala externae abolish male courtship behavior (Greenberg et al., 1984). This area receives olfactory information in other vertebrates, has afferents to the $\mathrm{AH}$ POA, and has been suggested to affect perception of social stimuli (reviewed in Kling and Brothers, 1992; Perkins et al., 1995). Little is known of possible behavioral functions of the septal area in reptiles, but this area does have afferent connections with the hypothalamus and in the green anole lizard is important in sociosexual behavior (Crews, 1979).

The differences in AR- and PR-mRNA expression between castrated P-sensitive and P-insensitive males could represent either (1) differential responses to intrahypothalamic progesterone administration or (2) intrinsic baseline differences in expression of these mRNA species. The lack of differences between control P-sensitive and P-insensitive animals argues against the second possibility. [Unimplanted intact males differing in courtship intensity representing these two populations also do not have differential baseline abundances of androgen receptor- or progesterone receptor-mRNA in these nuclei (D. Crews, J. Godwin, and M. Grammer, unpublished data)]. Progesterone is known to downregulate nuclear AR protein, but not cytosolic AR, in the AH-POA and pituitary of male guinea pigs administered either progesterone or the synthetic progestin agonist R5020 (Connolly and Resko, 1989). A progesteronemediated regulation of AR-mRNA could be important in the medial POA, because AR- and PR-mRNA are codistributed in this area. However, this seems unlikely in the lateral septum or amygdala externae, because no significant labeling of PR-mRNA is found in these areas (Young et al., 1994).

The finding that implanted P-insensitive males had significantly higher PR-mRNA abundance in both the medial and periventricular POA than P-sensitive males was not expected. As argued above, the lack of PR-mRNA differences in control P-sensitive and P-insensitive males suggests this difference between $\mathrm{P}$-sensitive and $\mathrm{P}$-insensitive males reflects differential downregulation of PR-mRNA in response to intrahypothalamic progesterone administration. Because the nonimplanted control group males were processed in a separate in situ hybridization procedure and are not an appropriate group for baseline comparisons to the implanted groups, we cannot say whether the greater PR-mRNA abundance in the implanted P-sensitive males reflects downregulation in P-sensitive males or upregulation in P-insensitive males. Likewise, the difference in AR-mRNA abundance could reflect either upregulation in $\mathrm{P}$-sensitive males or downregulation in P-insensitive males. However, it is known that progesterone downregulates its own receptor in both peripheral tissues and the ventromedial nucleus of the hypothalamus in female mammals (Selcer and Leavitt, 1988; Blaustein and Turcotte, 1990). This effect of progesterone is also seen with PR-mRNA in the ventromedial hypothalamus of female whiptail lizards (Godwin et al., 1996). These patterns suggest intrahypothalamic progesterone primarily is affecting the P-sensitive males, but this has not been conclusively shown.

It is curious that there was no difference in the abundance of AR or PR message relative to the side of the implant. One possible explanation is that hormone leaked from the implant site in the AH-POA into the systemic circulation, and hence both sides of the brain were exposed to hormone, leading to the bilateral regulation of AR- and PR-mRNA expression. However, extensive studies using the same technique in our and other laboratories indicate this unlikely, because implants nearby, but not in hormone target nuclei, fail to elicit mating behavior. Further, in the present study, three $\mathrm{P}$-sensitive individuals failed to respond to the intrahypothalamic implantation, and a single P-insensitive individual copulated after intrahypothalamic implantation. A second possibility is that the hormone implant stimulated steroid hormone-concentrating neurons in the ipsilateral AH-POA via activated hormone receptor-genome mechanisms as well as induced neurophysiological changes that were communicated via commissural connections to the contralateral nuclei, thereby regulating their hormone receptor expression. In this regard it is perhaps significant that, in general, unilateral intrahypothalamic implants into AH-POA are effective in restoring sexual behavior in castrated males, yet unilateral lesions of the AH-POA fail to abolish mating behavior in sexually intact males. It is possible that in both instances compensatory stimulation of the nuclei contralateral to the treated nuclei is responsible for the behavior.

There are several possible mechanisms by which progesterone could activate sexual behavior in castrated male whiptail lizards. First, progesterone may bind and activate AR. As in mammals, progesterone will bind the AR in lizards, albeit with less affinity than androgens, and high dosages lead to an inhibition of androgen-dependent responses (Bullock et al., 1978; Connolly and Resko, 1989; Lindzey and Crews, 1993). Also, there is a significant positive correlation between circulating levels of progesterone and the intensity of sexual behavior in intact male whiptail lizards (Lindzey and Crews, 1993). Second, the AR of whiptail lizards may be unusual in its affinity and specificity. However, the affinity and kinetics of the AR found in male whiptail lizards is comparable to that of mammalian AR (Lindzey and Crews, 1993). Third, progesterone may be converted to androgens or estrogens within the CNS. Neural conversion of steroid hormones is well documented in other vertebrate species, including mammals (Schlinger and Arnold, 1990). However, administration of R5020, a synthetic progestin that cannot be converted to other steroids, is as effective as progesterone in stimulating sexual behavior, and the antiprogestin RU486 inhibits the progesterone-induced reinstatement of sexual behavior in castrated whiptail lizards (Lindzey and Crews, 1988). A fourth possibility that has not been excluded by experiments is that progesterone may bind to and activate $\mathrm{PR}$ in neurons that are components of, or functionally linked to, neural circuits controlling male sexual behavior. As in the rat (Brown et al., 1987; Lauber et al., 1991), both AR and PR are codistributed and concentrated in the AH-POA of the sexual whiptail lizard (Young et al., 1994). Administration of androgen (testosterone or dihydrotestosterone) to gonadectomized whiptail lizards upregulates PR in the medial and periventricular POA (J. Godwin, V. Hartman, P. Nag, and D. Crews, unpublished data). The present report demonstrates that intrahypothalamic implantation of progesterone activates sexual behavior in castrated, P-sensitive males and, further, differentially regulates $\mathrm{AR}$ and $\mathrm{PR}$ in the medial and periventricular POA in P-sensitive, as compared with P-insensitive, males. The question to be answered now is whether $\mathrm{AR}$ and PR are colocalized in the same neurons or whether they reside in separate neurons that are in functional communication.

Progesterone activation of sexual behavior in male lizards has parallels in the laboratory rat. Androgen replacement therapy in castrated male rats does not reinstate sexual behavior in all individuals, and in those that do show sexual behavior to an 
estrous female, the behavior often is deficient. Further, administration of the antiprogestin RU486 to intact males inhibits the expression of aspects of sexual behavior (Witt et al., 1995). We have shown that, if physiological levels of progesterone are maintained in conjunction with androgen replacement therapy, complete sexual responses will be restored in castrated male rats (Witt et al., 1995). Indeed, the sexual behavior of these progesterone plus androgen-treated castrated males is equivalent to that of intact males. This is significant because castrated males given androgen replacement therapy alone usually never regain the full expression of sexual behavior. Also similar to the whiptail lizard, the medial POA and other nuclei in the AH-POA of rats express $\mathrm{PR}$ in both males and females, and no sex differences have been reported in the distribution or concentration of PR in the medial POA, although sex differences do occur in the ventromedial nucleus of the hypothalamus and the arcuate nucleus (Brown et al., 1987; Lauber et al., 1991).

The following has been established empirically: (1) the AHPOA is involved in the regulation of sexual behavior of males (2) and contains both AR and PR; (3) there exists a pronounced circadian pattern of progesterone secretion in males, and (4) progesterone synergizes with androgen to reinstate sexual behavior in castrated males, whereas (5) antiprogestin treatment leads to deficits in sexual behavior. Together, these indicate that progesterone and its interaction with its receptor play an important role in mediating androgen-dependent sexual behavior in males. The similarity of action of progesterone in both lizards and rats suggests that this hormone behavior interaction may be conserved evolutionarily and of fundamental importance to the control of sexual behavior in male amniote vertebrates.

\section{REFERENCES}

Bardin CW, Brown T, Isomaa VV, Janne OA (1984) Progestins can mimic, inhibit, and potentiate the actions of androgens. Pharmacol Ther 23:443-459.

Blaustein JD, Turcotte JC (1990) Down-regulation of progestin receptors in guinea pig brain: new findings using an immunocytochemical technique. J Neurobiol 21:675-685.

Bottoni L, Lucini V, Massa R (1985) Effect of progesterone on the male Japanese quail. Gen Comp Endocrinol 57:345-351.

Brown TJ, Clark AS, MacLusky NJ (1987) Regional sex differences in progestin receptor induction in the rat hypothalamus: effect of various doses of estradiol benzoate. J Neurosci 7:2529-2536.

Bullock LP, Bardin WC, Sherman MR (1978) Androgenic, antiandrogenic, and synandrogenic actions of progestins: role of steric and allosteric interactions with androgen receptors. Endocrinology 103:1768-1782.

Connolly P, Resko J (1989) Progestins affect reproductive behavior and androgen receptor dynamics in male guinea pig brain. Brain Res 305:312-316.

Crews D (1979) Neuroendocrinology of lizard reproduction. Biol Reprod 20:51-73.

Crews D, Silver R (1985) Reproductive physiology and behavior interactions in nonmammalian vertebrates. In: Handbook of behavioral neurobiology, Vol. 7, Reproduction (Adler NT, Pfaff DW, Goy RW, eds), pp 101-182. New York: Plenum.

Crews D, Traina V, Wetzel FT, Muller C (1978) Hormonal control of male reproductive behavior in the lizard, Anolis carolinensis: role of testosterone, dihydrotestosterone, and estradiol. Endocrinology 103:1814-1821.

Crews D, Wade J, Wilczynski W (1990) Sexually dimorphic areas in the brain of whiptail lizards. Brain Behav Evol 36:262-270.

Diamond M (1963) Progestogen inhibition of normal sexual behavior in the male guinea pig. Nature 209:1322-1324.

Ericksson CJ, Bruder RH, Komisaruk BR, Lehrman DS (1967) Selective inhibition by progesterone of androgen-induced behavior in male ring doves (Streptopelia risoria). Endocrinology 81:39-44.

Erpino MJ (1973) Temporary inhibition by progesterone of sexual behavior in intact male mice. Horm Behav 4:335-339.
Godwin J, Crews D (1995) Sex differences in estrogen and progesterone receptor messenger ribonucleic acid regulation in the brain of little striped whiptail lizards. Neuroendocrinology 62:293-300.

Godwin J, Hartman V, Grammer M, Crews D (1996) Progesterone inhibits female-typical receptive behavior and decreases hypothalamic estrogen and progesterone receptor messenger ribonucleic acid levels in whiptail lizards (genus Cnemidophorus). Horm Behav 30:138-144.

Greenberg N, Scott M, Crews D (1984) Role of the amygdala in the reproductive and aggressive behavior of the lizard, Anolis carolinensis. Physiol Behav 32:147-151.

Griffo W, Lee CT (1973) Progesterone antagonism of androgendependent marking in gerbils. Horm Behav 4:351-358.

Kalra PS, Kalra SP (1977) Circadian periodicities of serum androgens, progesterone, gonadotropins, and luteinizing hormone-releasing hormone in male rats: the effects of hypothalamic deafferentation, castration, and adrenalectomy. Endocrinology 101:1821-1827.

Kingston PA, Crews D (1994) Role of the AH-POA in the control of courtship and copulatory behavior in sexual and unisexual whiptail lizards. Brain Res 643:349-351.

Kling AS, Brothers LA (1992) The amygdala and social behavior. In: The amygdala: neurobiological aspects of emotion, memory, and mental dysfunction. (Aggleton JP, ed), pp 353-377. New York: Wiley-Liss.

Lauber A, Romano B, Pfaff D (1991) Gene expression for estrogen and progesterone receptor mRNAs in rat brain and possible relations to sexually dimorphic functions. J Steroid Biochem Mol Biol 40:53-62.

Lindzey J, Crews D (1986) Hormonal control of courtship and copulatory behavior in male Cnemidophorus inornatus, a direct sexual ancestor of a unisexual, parthenogenic lizard. Gen Comp Endocrinol 64:411-418.

Lindzey J, Crews D (1988a) Effects of progestins on sexual behavior in castrated lizards (Cnemidophorus inornatus). J Endocrinol 119:265-273.

Lindzey J, Crews D (1988b) Psychobiology of sexual behavior in a whiptail lizard, Cnemidophorus inornatus. Horm Behav 22:279-293.

Lindzey J, Crews D (1992) Individual variation in intensity of sexual behaviors in captive male Cnemidophorus inornatus. Horm Behav 26:46-55.

Lindzey J, Crews D (1993) Effects of progesterone and dihydrotestosterone on stimulation of androgen-dependent sex behavior, accessory sex structures, and in vitro binding characteristics of cytosolic androgen receptors in male whiptail lizards (Cnemidophorus inornatus). Horm Behav 27:269-281.

Perkins A, Fitzgerald JA, Moss GE (1995) A comparison of LH secretion and brain estradiol receptors in heterosexual and homosexual rams and female sheep. Horm Behav 29:31-41.

Rozendaal JC, Crews D (1989) Effects of intracranial implantation of dihydrotestosterone on sexual behavior in male Cnemidophorus inornatus, a direct sexual ancestor of a parthenogenetic lizard. Horm Behav 23:194-202.

Sachs B, Meisel RL (1994) The physiology of male sexual behavior. In: The physiology of reproduction, Vol. 2 (Knobil E, Neill J, eds), pp 3-106. New York: Raven.

Schlinger BA, Arnold AP (1990) Brain is the major site of estrogen synthesis in a male songbird. Proc Natl Acad Sci USA 88:4191-4194.

Selcer KW, Leavitt WW (1988) Progesterone down-regulation of nuclear estrogen receptor: a fundamental mechanism in birds and mammals. Gen Comp Endocrinol 72:443-452.

Wade J, Huang J-M, Crews D (1993) Hormonal control of sex differences in the brain, behavior, and accessory sex structures of whiptail lizards (Cnemidophorus species). J Neuroendocrinol 5:81-93.

Witt DM, Young LJ, Crews D (1994) Progesterone and sexual behavior in males. Psychoneuroendocrinology 19:553-562.

Witt DM, Young LJ, Crews D (1995) Progesterone modulation of androgen-dependent sexual behavior in male rats. Physiol Behav 57:307-313.

Young LJ, Greenberg N, Crews D (1991) The effects of progesterone on sexual behavior in male green anole lizards (Anolis carolinensis). Horm Behav 25:477-488.

Young LJ, Lopreato GF, Horan K, Crews D (1994) Cloning and in situ hybridization of estrogen receptor, progesterone receptor, and androgen receptor expression in the brain of whiptail lizards (Cnemidophorus uniparens and C. inornatus). J Comp Neurol 347:288-300.

Young LJ, Nag P, Crews D (1995) Regulation of estrogen and progesterone receptor messenger ribonucleic acid by estrogen in the brain of the whiptail lizard (Cnemidophorus uniparens). J Neuroendocrinol 7:119-125.

Zar JH (1984) Biostatistical analysis. Englewood Cliffs, NJ: Prentice-Hall. 